\title{
Playing Deaf and Dumb: Disability and the Contemporary Theatre
}

\begin{abstract}
This paper explores how the "otherness" of disability continues to occupy the periphery of theatre internationally, due in part to the movement of the "otherness" of race to the centre. This paper questions why, in an age of gender and race requirements in casting, similar requirements are markedly absent or impossible with regard to disability. Even in dramas that feature disabled characters, the dramatic structure itself can make the participation of a disabled actor impossible. For example, act 1 of Bruce Norris's Tony Awardand Pulitzer Prize-winning drama Clybourne Park (2012) features a deaf young woman. The requirements of staging seem to offer no barriers to the participation of a deaf actor until the second act, when it becomes apparent that the drama requires that the same actor double in a non-deaf role. As the actor appears in the second role, the audience can indulge in a moment of aesthetic distancing: "ah, she was playing deaf." The disabled body is displaced from the centre after having served as the narrative crutch to support the drama's argument about race in America. In the particular case of Clybourne Park, I will demonstrate that the drama's fundamental message relies on the presence of an able-bodied actor to double as disabled, in order to embody a vision of a future in which racism, like deafness, can be "cured."
\end{abstract}

Keywords: disability, drama, race, racism, theatre

Furore over the casting requirements for the runaway Broadway hit Hamilton, and the complete absence of artists of colour from the 2016 Academy Award nominations, reignited the loaded debate over racial and gender equality in the performing arts. In 2015, the Gilbert and Sullivan Society of New York City was forced to cancel a production of The Mikado days before opening due to a public outcry over "actors in yellow face" (Kim 2016). Only in 2015 did the New York Metropolitan Opera discontinue the practice of a singer performing the title role of Verdi's Otello in blackface (Cooper 2015). In terms of gender equality in the performing arts, movements like the "50/50 in 2020" initiative by the League of Professional Theatre Women seek "to achieve parity for professional women theater artists by 2020"; they still "receive fewer than $20 \%$ of the professional production opportunities nationwide" in the US ("50/50 in 2020" 2017). African American actors have come from a place of near-total exclusion from working in professional theatre to 
a place where - thanks to the civil rights movement and the work of black playwrights - non-traditional casting and plays about the black experience in America are becoming standard choices. This revolution in actor training and casting came about in part because of the early commitment of artist-directors like Joseph Papp of New York's Public Theatre and Bill Bushnell of the Los Angeles Theatre Center to non-traditional casting for all their productions (Lewis 2010, 180). A movement to welcome minority races and female voices to the centre of theatrical production (and therefore power) has begun, and we should celebrate it.

But victories in the representation of race and gender have come in part thanks to the wilful blind eye of scholars, directors, actors, and writers to the ubiquity of "ableism" in the theatre. In fact, the most prevalent casting requirement in the profession today is able-bodiedness, as the theatre world - from its physical structures to its dramatic texts - requires the actor to be able-bodied and to "put on" the otherness of disability. Too often, practical concerns allow theatre practitioners, producers, and spectators to "play deaf and dumb" to how the drama contributes to the ongoing repulsion of the disabled from the centre of intellectual and professional artistic flourishing. ${ }^{1}$ A series of structural impediments - physical, theoretical, and dramatic - form a barrier to the full participation of disabled performers in professional theatre. In the particular case of Bruce Norris's Clybourne Park (2012), I will demonstrate that the drama's fundamental message relies on the presence of an able-bodied actor to double as disabled, in order to embody a vision of a future in which racism, like deafness, can be "cured."

Despite several decades of disability-rights activism, professional theatre continues to produce stories about disability while refusing entrance to the disabled body as a performing body to a shocking degree, especially when considered in contrast to the progress made by artists of colour. In the case of casting that is ability-sensitive, some playwrights have required that professional productions of their plays seek out actors with the (dis)abilities required of the role, but such licensing restrictions remain rare. Allison Considine, in American Theatre, writes:

It's not as if stories about people with disabilities are rare: The past two seasons on Broadway showcased seven productions featuring disabled characters; none of them were played by actors with disabilities. And while the Great White Way is just one slice of the landscape

1 Brian Eugenio Herrera (2017) asked a similar question in a recent analysis of university casting practices for Latinx plays entitled "But Do We Have the Actors for That?” The question raised by Herrera concerning Latinx actors and disabled actors is: do the universities and conservatories need to lead the way by training performers who are not white/able-bodied? Or do playwrights, producers, and directors need to lead the way in opening the profession? 
of the American theatre, the casting of these commercial productions - many of which typically get their start at nonprofits - is emblematic of the country as a whole. (Considine 2015)

Considine references simultaneously the ubiquitous practice of able-bodied actors portraying disabled characters alongside the economic system by which new work is produced - in which regional and non-profit theatres solicit the work of new playwrights to feed new works to Broadway. This system reinforces the pattern of denying accountability when it comes to writing roles and not requiring disability-specific casting.

Disability studies has given us terms with which to understand how we approach and understand disabled bodies against a common understanding of the normal, able-bodied self. Works such as Rosemarie Garland Thomson's Extraordinary Bodies: Figuring Physical Disability in American Culture and Literature (1997) have shown the dependence of so-called normal people on disabled bodies to construct a position of narrative superiority. Without the aberrant, the congenitally defective, and the diseased as the dramatic foil, the "normate" would not exist. Mitchell and Snyder $(2000,6)$ make the radical claim that "disability inaugurates the act of interpretation." Whether presented onstage and represented through acting (an adopted limp, sitting in a wheelchair, elaborate make-up to mimic disfigurement), or represented aurally (described in the dialogue itself and visualized by the audience's imagination), disabled characters carry an excess of meaning against which "normal" characters signify their acceptability. ${ }^{2}$

In the medium of the popular and critically acclaimed theatre of Broadway and the West End, playwrights, producers, and directors frequently choose to elevate dramas that feature disabled characters at a time when little political or economic empowerment has accrued to disabled theatre artists. Artists with disabilities remain ghettoized, for the most part, in disability theatre projects where the "punch" of their actual presence can be safely contained. ${ }^{3}$ Because of this absence, a powerful rhetorical device occurs at the conclusion of nearly all plays featuring disabled characters. The actor emerges for the final bow "cured" of whatever impairment had been the central fact of the character: lameness, blind-

2 Stacy Wolf (2005) provides a fascinating analysis of how two recent plays chose to represent disability entirely through description, keeping the disabled body "invisible."

3 Kirsty Johnston (2016) provides an excellent overview of the disabled in theatre and the politically charged movement known as disability theatre. 
ness, deafness, and so on. The illusion of the disabled body has been erased, and the applause for an excellent performance is bestowed on the normal body. In the performing arts, the normal body is inscribed with various positive meanings, in large part because the abnormal or disfigured body has carried negative inscriptions within the narrative itself. Christopher Shinn calls this phenomenon "reassuring" as audiences can relax, knowing that "we are not witnessing the actual pain and struggle of real disabled human beings" (quoted in Johnston 2016, 43). The able-bodied actor's presence is actually required by any drama that features disability because the final transformation at the bows allows the two major disability metaphors - "the triumph of the human spirit, or the freakishness we all feel inside," as Shinn pithily summarizes them - to resonate without difficulty, and forecloses further questions about the nature of disability (Johnston 2016, 43). The normal body is capable of astonishing acts of verisimilitude as the disabled body is forgotten, or - as Joseph Roach (1989) more menacingly puts it - erased.

Thus, when examining representations of disabled figures in drama, the theatre historian must look not only at how the body signifies within the narrative, but also at how the absence of an actual disabled body on the stage signifies. The theatre produces a series of bodily images - some of which it inscribes, according to Joseph Roach, as ideal. To reinforce certain kinds of bodies as ideal, the theatre must circulate disfavoured bodily images, which Roach says are "occluded" in a process of erasure $(1989,159)$. Rosemarie Garland Thomson summarizes the power of disability to signify the negative while simultaneously highlighting the desirability of ordinary life when she writes that "disabled figures function as discursive lightning rods for complex social tensions [...] for the pity, fear, discomfort, guilt, or sense of normalcy of the reader or a more significant character" $(1997,17)$. In all but the rarest exceptions, erasure has both a narrative dimension - the death of the dissolute, diseased, immoral, or bitter disabled figure - and a phenomenological dimension - the disappearance of the "put-on" disabled body in the final bows of professional, award-winning actors, thanks in large part to the near-total absence of actual disabled performers.

Disabled people frequently deride how writers use disabled characters as short cuts to inspiration, now called "inspiration porn."4 Conversely, the question of disabled performers portraying so-called "normal" characters also remains highly problematic. The implicit bias of casting means that - much like unstated expectations that the majority of roles are intended to be played by white actors -

4 ABC's sitcom Speechless satirized our love of "inspiration porn" in the 11 January 2017 episode, "H-E-R-HERO," in which the main character, J. J., who has cerebral palsy, must put up with his brother shamelessly using his inspiring story to win an essay contest. 
those with the authority to make casting decisions can comfortably assume that, unless a role has been written as "crippled," casting a disabled actor need not even merit consideration. Due to our narrative reliance on disability to communicate themes and character traits (evil, fallenness, bastardy, social dissolution/ inspiration, goodness, humility, cure), casting a disabled actor in a non-disabled role would change the meaning of the play, as the disability would signify authorial intention where there had been none (Sandahl 2005, 255). Casting directors and producers continue to rely on a variant of this so-called fidelity to authorial intention and other more pragmatic arguments when defending their choices. In an age in which race-blind and gender-bending casting is becoming increasingly the norm, the question must be confronted: are the disabled a different kind of "Other," such that the reasons that support actor training, race-blind casting, and the commissioning of new dramatic works to reflect lived experience as a minority group, do not apply to them?

LINDNER: We feel that most of the trouble in this world, when you come right down to it - most of the trouble exists because people just don't sit down and talk to each other. (Hansberry 1987, 116)

I will now consider how disability interacts with race as a subject matter in contemporary drama. Bruce Norris's Clybourne Park (2012) and Kwame Kwei-Armah's Beneatha's Place (2013) both take Lorraine Hansbury's A Raisin in the Sun (1987) as their point of departure and imagine the lives of the characters following Mrs Younger's purchase of a home in a white Chicago neighbourhood. Both casts feature black and white characters, and both dramas examine the dynamics of place, community, family, and race. In the case of Clybourne Park, the play is set in the talked-of house purchased by the Youngers in A Raisin in the Sun - at the time of its sale in 1959 and then fifty years later when a white couple (Lindsey and Steve) have bought the property and plan to tear down the house and rebuild a much larger one on the same lot. Clybourne Park follows the story of Russ and Bev Lindner, who are selling their Chicago home and planning to move to the suburbs. Their son Kenneth died by suicide in that home some months earlier. Due to the scandal, the home's value has decreased, and the Lindners plan to sell to a black family (the Youngers of $A$ Raisin in the Sun). The community finds out and responds by arriving at the Lindner home, in the person of Karl, accompanied by his wife Betsy, to pressure Russ and Bev not to sell.

In Clybourne Park, all of the actors play two roles, and the character list informs the reader that in act 2 we meet "Lindsay (played by the character who 
played Betsy)," "Kathy (played by the actor who played Bev)," and so on (Norris 2012, 4). Each character's (and therefore each actor's) race is specified in the act 1 character descriptions. Beneatha's Place follows the story of Beneatha Younger, who at the end of $A$ Raisin in the Sun married the scholar and Nigerian activist Joseph Asagai Funmilayo and moved to Nigeria. The two acts of the play take place in Beneatha's house in Nigeria - upon her first arrival during decolonization and then her return, forty years later, after a long and distinguished career as a professor of African American Studies. Beneatha and her junior colleagues are in Lagos for an international conference of social sciences. The cast list of the performance script (as yet unpublished; Kwei-Armah 2013) does not require doubling between the two acts, but does suggest possible doubles (a white missionary character in act 1 could return in act 2 as a "Professor of English and African American Studies," and so on). Unlike Clybourne Park, the main character, Beneatha, returns in act 2, and her connection to the house, to the history of racism and civil rights over the preceding forty years, to decolonization, and to the current state of race relations in America and internationally makes her a touchstone character for the audience. Beneatha's Place was written in response to Norris's Clybourne Park and was produced alongside it during the 2013 season at Baltimore's Center Stage.

Clybourne Park does not indicate Betsy's disability in the cast list. She is listed as "married to Karl, late 20s" (Norris 2012, 5). ${ }^{5}$ Only when she enters the scene does the script indicate her disability: "The front door opens. Karl escorts his wife, Betsy, who is eight months pregnant, and who also happens to be totally deaf" (24). The off-handed "happens to be" that describes Betsy's deafness recurs in spoken dialogue when Karl attempts to create a logical and yet veiled argument for why Russ should not sell his house to an African American family.

Betsy happens to be deaf, just like she "happens to be" Scandinavian. As Karl jokes, "my wife Betsy, now, Betsy's family happens to be Scandinavian, and on holidays they eat a thing known as lutefisk. And this is a dish, which I can tell you - (He chuckles.) - is not to my liking at all. It's - oh my goodness, let's just say it's gelatinous" (32). In the same way that Betsy "happens to be" deaf, she also happens to be heavily pregnant, another convenient character trait for the plot. Her pregnancy serves as further justification for all of the characters to coddle and patronize her. Upon Betsy's entry, Bev screeches at her:

5 Subsequent references to specific passages in this play will be made by parenthetical page number in the body of the text. The use of italics and square brackets in quotations from Clybourne Park and Beneatha's Place follows the original in all cases. 
BEV. (Over-enunciating for Betsy's benefit.) Well just look at you! My goodness. You are just the biggest thing.

BETSY. Ah nohhh! Eee toooor. Ah so beee!!! [I know. It's true. I'm so big!!!! (24)

Unable to speak for herself, her abilities or disabilities, or her culture, Betsy is talked about, talked over, and always talked to as a child. Karl obsessively worries about and manages her every action - in part because she lost a child to stillbirth two years prior (Betsy's body is now doubly suspect in its inability to fulfil ordinary functions). Karl even intervenes to correct how she drinks her tea, admonishing "Slow sips. Small sips" (26). She is both infantile and perpetually at risk of harming herself.

From Betsy's entrance, she is a figure of comic relief. Enormously pregnant, having been kept in the car like a dog, and blankly smiling and affable, Betsy is unaware completely of the argument swirling around her. Although several characters, including her husband, have the ability to sign the alphabet (badly), no actual sign language is used to facilitate communication with her. She appears to have some residual hearing, as evidenced by lines of hers like "Eeeen ahhhh hurrrhhh daaaaaa! [Even I heard that!]” (30). This line received an enormous laugh at the Mad Cow Theatre Production in Orlando in 2015. But despite the ability to lip-read and decode speech when it is shouted directly at her, Betsy cannot participate in the conflict of act 1 . She is pushed aside by her husband, who is characterized as the racist neighbourhood watchman. When Russ insists that Karl leave his home for daring to invoke Kenneth's suicide as blackmail, Betsy again proves that she has not understood anything:

BETSY. (Quietly, before the door is closed.) Kaahhh, what happaahh? (36)

In Clybourne Park, Betsy's deafness is a metaphor for the blissful ignorance of white America in both the past and the present to the racist language and activity swirling around their uncomprehending ears. Her position as metaphor rather than character crystallizes in the dialogue which received the largest laugh of the entire play. When Karl storms back into Russ and Bev's home, followed by Betsy, to try one last time to convince Russ not to sell his home to an African American, Russ responds:

RUSS. And you can go fuck yourself.

KARL. Well that is over the line, mister. That is not language I will tolerate in front of my wife. RUSS. (Beat, then.) She's deaf, Karl!! Completely - (Waving to Betsy, fake-jolly.) Hello, Betsy! Go fuck yourself! (Betsy smiles, waves back.) (39) 
In this moment, Betsy's isolation and alienation are complete. Uncomprehending, unable to lip-read, and with no one able to use sign language, Betsy is not included in this racist microcosm of American society. Spectator laughter at Betsy erases the contextual frame between us and them, then and now. By collapsing the comfortable distinction between a postmodern present and pre-civil rights racist America, Norris might have paved the way for a deeply uncomfortable commentary on how we still stereotype, dehumanize, and exclude those who manifest distinctly "Other"-ed bodies. But the narrative structure of the play conveniently erases deafness from within the story and the possibility of a deaf actor portraying Betsy.

When act 2 begins, and the actor playing Betsy reappears as Lindsey, an able-bodied career woman, the audience's experience of Betsy's deafness is revised and re-inscribed with new meanings. As the contemporary story unfolds, the audience receives information about Betsy's deafness that reinforces middle-class expectations of cure, and provides another level of metaphor for the play's major theme of racism: Betsy's deafness was not, in fact, heritable. The character of Kathy, the lawyer negotiating on behalf of the new, white owners of the property, is the child that Betsy had been pregnant with in act 1 . This revision of Betsy's deafness further enforces the play's problematic, ableist narrative because the audience can now rest easy knowing that the pregnant Betsy was not, in fact, carrying a potentially deaf child.

Like deafness, American racism might also be "curable" over the course of several generations. The play generates what Ato Quayson calls "aesthetic nervousness" by both portraying and provoking in the spectator "attitudes to disability that themselves often remain unexamined in their prejudices and biases" (Quayson 2007, 15). Act 2 opens in 2009 in the living room of the now-derelict house after several decades of "white flight" to the Chicago suburbs. The metaphor of deafness recurs in act 2 as the characters spar over property rights and community standards by trading racist and sexist jokes. Curiously, as each character shares offensive jokes, the characters of Lindsey and Kathy cannot "hear" why they are funny. Whereas Betsy in act 1 had lacked a sense of hearing, Lindsey and Kathy lack a sense of humour, and in a dramatic structure that mirrors act 1 , the women's deficiency is the butt of the final joke of act 2.

LENA. Why is a white woman like a tampon?

[...]

They're both stuck up cunts. (77)

The two white women react with extreme displeasure at the joke, as they have at the previous jokes. 
KATHY. An extremely hostile joke.

LINDSEY. Directed at me. (78)

Jack L. B. Gohn characterizes the performative quality of the jokes as forcing "a double-bind choice" on those present: "Get angry (and thus appear unable to take a joke) or not (and show oneself lacking in group solidarity and self-respect) [...]. Tell the joke (and give offense) or don't tell the joke (and be dishonest about how you feel about those elephants that may inhabit the room)" (Gohn 2013, 576). Lindsey's lack of humour parallels Betsy's simultaneous inability to "get" that she is the butt of Russ's joke and her indefatigable good humour at being treated as a perpetual child. We laugh at Lindsey because she is a "stuck up cunt" who cannot take a joke, but we fail to discern that we have laughed at Betsy because she cannot hear. By erasing deafness in the second act of the play, the communal laughter shared by the audience at Betsy's disability is never challenged.

Kwame Kwei-Armah's Beneatha's Place (2013) arose out of a desire to counter what he saw as "the implicit message of Clybourne Park [...] and which he has stated bothered him [...] that whites build and blacks destroy" (Gohn 2013, 571572). The play can certainly be read as responding to Norris's depiction of the derelict neighbourhood of Clybourne Park. Simultaneously, however, Kwei-Armah consistently responds to Norris's implicit message that, for blacks and whites to achieve racial healing, they should do so by uniting in pity and mockery against those who are called in Clybourne Park "so sad," "Wow. Depressing," the "goddamn retarded kid," and those of whom it is said: "There but for the grace of God” go I (Norris 2012, 10-11, 37, 65). Kwei-Armah goes so far as to quote Norris's play by having Beneatha recite one of the same jokes that brought Clybourne Park to its climax. This creates the interesting effect of dramatizing a joke being told around the world simultaneously - in Clybourne Park, in southern California, and in Nigeria:

BENEATHA: You know, I sat in the cafeteria of our very liberal campus the other day and I heard a young man recite a joke he'd heard. "What's long and hard on a black male?" "First grade.” And all around, black and white started laughing.

WALE: You dealt with him good, right?

BENEATHA: Oh no, I didn't say a thing. I was pleased that he felt free enough to say it in my presence. It indicates either great social progress or ...

WALE: ... That we're the butt of everyone's jokes?!

(She looks at the coon masks and gives a "Huh." Her "huh" has the tone of "hasn't it ever been thus?”) (Kwei-Armah 2013, act 2)

As audiences on Broadway and at many regional theatres succumb to Norris's false "double-bind" by choosing to either laugh at the joke or withhold their 
laughter, audiences at Beneatha's Place encounter a narrative that refuses an easy answer to the problem of racial division. Beneatha's place remains the central metaphor around which the narrative organizes itself, not difference (either racial or ability-based difference). Beneatha's Place reveals the false choice endemic in American conversations about race: to be with us, you must unite with us against some other. Kwei-Armah has instead constructed an open-ended narrative that does not rely on the crutch of disability for its force.

BENEATHA: The only real way to control the future, is not just to own yesterday, but to give people the space to tell you what they really think about you today. (Kwei-Armah 2013, act 2)

Why does an analysis like the preceding one matter in terms of disability rights and theatre? Disability theatre as a physical, theoretical, and literary space has grown as a political force for the "other" presence that has suffered such astonishing erasure from public (re)presentation. Or has it? A quick survey of the Tony Award-winning new plays since 1960 reveals that thirteen of the winners - or twenty-eight percent - have featured disabled characters as central to the plot. Their disabilities include blindness, deafness, physical deformities, developmental disabilities, dementia, AIDS, and autism. Despite the astonishing ubiquity of disability as a narrative device in dramatic literature, it rarely receives analysis, in part because, as Lennard J. Davis (1998) claims, cure narratives are as flawed as the culture of medical cure that produces them. "Modern subjectivity is a wounded identity that cannot cure itself without recourse to cure narratives," he writes, "which means that it cannot cure itself at all, since the disability of modern subjectivity is inherent in the environment not in the subject" (Davis 1998, 332). The problem is actually political, not narrative; the multitude of competing identities, each vying for position as the "best" or "worst off" - is a symptom of a society with deep structural inequities. Davis claims that cure narratives will continue to reinforce the status of the disabled as the most "sad" and "depressing" because "other identity groups will not cede their place of priority" (1998, 333). Although the case study of Norris's Clybourne Park seems to support Davis's pessimism about a possible future in which other minority groups would welcome the disabled into the centre, the comparison with Kwei-Armah's dramatic riposte offers a refreshing counter-example. Sometimes the people who are not laughing in the audience are not caught in a double bind because they form a third party. They are the ones who are once again hearing what the playwright, director, and their fellow audience members really think about them today. 


\section{Works cited}

Considine, Allison. "Theatre Artists With Disabilities are Ready, Willing, and, Yes, Able." American Theatre 20 October 2015. http://www.americantheatre.org/2015/10/20/theatreartists-with-disabilities-are-ready-willing-and-yes-able/ (27 September 2017).

Cooper, Michael. “An ‘Otello' Without Blackface Highlights an Enduring Tradition in Opera." The New York Times 17 September 2015. https://www.nytimes.com/2015/09/20/arts/ music/an-otello-without-the-blackface-nods-to-modern-tastes.html (30 November 2017).

Davis, Lennard J. 'Who Put the 'the' in 'the Novel?' Identity Politics and Disability in Novel Studies." Novel: A Forum on Fiction 31.3 (1998): 317-334.

“50/50 in 2020." theatrewomen.org. League of Professional Theatre Women, 30 June 2016. http://www.theatrewomen.org/programs/5050-in-2020-parity-for-women-theatre-artists/ (12 July 2016).

Gohn, Jack L. B. “There Goes the Neighborhood.” The Hopkins Review 6.4 (2013): 570-580.

Hansberry, Lorraine. A Raisin in the Sun. Ed. Robert Nemiroff. New York: New American Library, 1987.

“H-E-R-Hero.” Speechless. ABC. Season 1. Episode 12. 11 January 2017. http://www.amazon. com/Speechless-Season-1/dp/B01LFSSLSS.

Herrera, Brian Eugenio. “'But Do We Have the Actors for That?': Some Principles of Practice for Staging Latinx Plays in a University Theatre Context.” Theatre Topics 27.1 (2017): 23-35.

Johnston, Kirsty. Disability Theatre and Modern Drama: Recasting Modernism. London: Bloomsbury Methuen Drama, 2016.

Kim, E. Tammy. “An Asian-American Re-Imagining of Gilbert and Sullivan's ‘The Mikado.” The New Yorker 27 December 2016. http://www.newyorker.com/culture/culture-desk/ an-asian-american-reimagining-of-gilbert-and-sullivans-the-mikado (27 August 2017)

Kwei-Armah, Kwame. Beneatha's Place. Rehearsal Draft 1. 14 May 2013.

Lewis, Victoria Ann. "Disability and Access: A Manifesto for Actor Training." The Politics of American Actor Training. Ed. Ellen Margolis and Lissa Taylor Renaud. New York: Routledge, 2010. 177-197.

Mitchell, David T., and Sharon L. Snyder. Narrative Prosthesis: Disability and the Dependencies of Discourse. Ann Arbor: University of Michigan Press, 2014.

Norris, Bruce. Clybourne Park. New York: Dramatists Play Service, 2012.

Quayson, Ato. Aesthetic Nervousness: Disability and the Crisis of Representation. New York: Columbia University Press, 2007.

Roach, Joseph. "Theatre History and the Ideology of the Aesthetic." Theatre Journal. 41.2 (1989): 155-168.

Sandahl, Carrie. "The Tyranny of Neutral: Disability and Actor Training." Bodies in Commotion: Disability \& Performance. Ed. Sandahl and Philip Auslander. Ann Arbor: University of Michigan Press, 2005. 255-268.

Thomson, Rosemarie Garland. Extraordinary Bodies: Figuring Physical Disability in American Culture and Literature. New York: Columbia University Press, 1997.

Wolf, Stacy. “Disability's Invisibility in Joan Schenkar's Signs of Life and Heather McDonald's An Almost Holy Picture." Bodies in Commotion: Disability \& Performance. Ed. Carrie Sandahl and Philip Auslander. Ann Arbor: University of Michigan Press, 2005. 302-318. 
Marianne DiQuattro's research intervenes at the intersection of literature, philosophy, and theatre studies. She is artistic director of Running Man Theatre Company, a disability theatre company in Central Florida. 